\title{
ENVIRONMENTAL INFLUENCE ON THE DEVELOPMENT OF SOCIAL SKILLS IN CHILDREN
}

\author{
Maria Luiza Marinho-Casanova \\ Universidade Estadual de Londrina \\ maluuel@gmail.com \\ Marie Leiner \\ Texas Tech University Health Sciences Center - EUA \\ marie.leiner@ttuhsc.edu
}

\begin{abstract}
This paper aims to present data from a narrative review of the literature on some child behaviors taken as socially skilled in Brazilian culture, and to highlight the importance of social skill to the healthy development of a child. Self-control, cooperation, civility, empathy, and skillful academic practice are some of the behaviors pointed out by literature as being socially skillful. The development of such behaviors stems in childhood, during the interactions with parents as well as with other adults, and with their peers during the first years of school. Some children who do not develop a socially skillful repertoire, may learn other behaviors that contribute to the establishment of negative interactions between them and the social group. The aspects of children's education discussed in this work are supported by extension projects with children considered at risk and can to support teachers and parents to prevent children's behavioral problems, thereby avoiding learning and socialization difficulties in childhood and adolescence.
\end{abstract}

Key words: Social Skills. Child Development. Prevention. Behavior Analysis.

\section{INFLUÊNCIA DO AMBIENTE NO DESENVOLVIMENTO DE HABILIDADES SOCIAIS EM CRIANÇAS}

Resumo

Este artigo tem como objetivo apresentar dados de uma revisão narrativa da literatura sobre alguns comportamentos infantis considerados socialmente habilidosos na cultura brasileira e destacar a importância da habilidade social para o desenvolvimento infantil saudável. Autocontrole, cooperação, civilidade, empatia e prática acadêmica são alguns dos comportamentos apontados na literatura como sendo socialmente habilidosos. $\mathrm{O}$ desenvolvimento de tais comportamentos ocorre na infância, durante as interações com pais, outros adultos e com pares durante os primeiros anos de escolarização. Algumas crianças que não desenvolvem esse repertório podem aprender outros comportamentos que contribuem para o estabelecimento de interações negativas entre elas e o grupo social. Os aspectos da educação infantil discutidos neste trabalho têm justificado ações de projetos de extensão com crianças em situação de risco social e podem subsidiar professores e pais para prevenir problemas comportamentais em crianças, evitando dificuldades de aprendizagem e socialização na infância e na adolescência.

Palavras-chave: Habilidades Sociais. Desenvolvimento Infantil. Prevenção. Análise do Comportamento.

\section{INFLUENCIA AMBIENTAL SOBRE EL DESARROLLO DE LAS HABILIDADES SOCIALES EN LOS NIÑOS}

Resumen

Este artículo tiene como objetivo presentar datos de una revisión narrativa de la literatura sobre algunos comportamientos infantiles considerados socialmente habilidosos en la cultura brasileña y resaltar la importancia de la habilidad social para el desarrollo infantil sano. El autocontrol, la cooperación, la civilidad, la empatía y la hábil práctica académica son algunos de los comportamientos señalados por la literatura como socialmente hábiles. El desarrollo de tales comportamientos se origina en la infancia, durante las interacciones con sus padres, con otros adultos, y con sus compañeros durante los primeros años de la escuela. Algunos niños que no desarrollan un repertorio socialmente hábil pueden aprender otros comportamientos que contribuyen al establecimiento de interacciones negativas entre ellos y el grupo social. Los aspectos de la educación infantil discutidos en este trabajo han justificado acciones de proyectos de extensión con niños en situación de riesgo social y pueden apoyar a maestros y padres para prevenir los problemas de conducta de los niños, evitando las dificultades de aprendizaje y socialización en la infancia y la adolescencia.

Palabras clave: Habilidades Sociales. Desarrollo Infantil. Prevención. Análisis de la Conducta. 
Environmental influence on the development of social skills in children

\section{INTRODUCTION}

Recently, researchers and clinical experts in child development have suggested the importance of appropriate child interactions with peers and adults, in order to develop a global behavioral repertoire that is adequate to the numerous contexts the child lives in. During regular daily activities, an individual relates with people through some kind of social interaction. This social development begins during childhood with parental and other adult interactions, and later on with other children/peers (Marinho, 2003, Reid, Patterson \& Snyder, 2002, Gomide, 2001). Empathic behavior, problem solving skills, adequate expression of both positive and negative feelings, self-control, and other social skills, become extremely necessary behaviors in childhood as they allow positive interactions with the peers and others, and are necessary to develop a healthy behavioral repertoire in life (Rodrigues \& Marinho, 2007).

What defines a healthy development or an adequate behavior depends on a socialcultural context in which these concepts will be evaluated (Ullman \& Krasner, 1975). It can be affirmed that self-control, empathic, cooperative behaviors are some categories defined as social skills in occidental cultures (Rodrigues \& Marinho, 2007). These behaviors make interpersonal relationships easier.

It is necessary to establish socially-cultural contingencies in order to develop these behaviors from childhood, so they can be learned from interactions with other peers and adults when development is facilitates. This is a protective factor for the child who would have a maladjusted behavior (Marinho-Casanova, 2015, Leiner, 2010, Marinho e Caballo, 2001).

The purpose of this paper is to examine concepts that increase or develop prosocial behaviors among at-risk children and adolescents. Examples of extension projects include projects such as "Values School" and "Animated educational cartoons to prevent violence and drug use" from the Universidad Estatal de Londrina, Brazil. Activities included in these projects involve weekly activities with children and adolescents exposed to problems such as poverty, school failure, drugs, (Marinho-Casanova, 2015) as well as teacher trainings (Leiner y Marinho-Casanova, 2011; 2014).

In this sense, this paper aims to present some child behaviors taken as socially skilled in Brazilian culture both to scholars and preschoolers. Additionally, this paper will discuss the concept of social skills, it will present some components to this behavioral range, and it will highlight the importance of social skill to the healthy development of a child. 
Environmental influence on the development of social skills in children

\section{THE CONCEPT OF SOCIAL SKILLS}

In scientific evidence, many definitions about social skills are found. Authors (Caballo, 2003, Del Prette \& Del Prette, 1999) agree to define social skills as learned behavioral abilities in social interactions. According to Del Prette and Del Prette (2001), the term social skills refer to the, "existence of different ranges of social behavior in the individual repertoire to deal adequately with interpersonal situations", which changes according to the individual's stage of development. Agreeing to that, Caballo (2003, p.6) says that, "socially skilled behavior is a group of behaviors in an interpersonal context, expressing feelings, attitudes, wishes, opinions or rights, in an adequate manner to the situation, respecting these behaviors in others, usually solving immediate problems and decreasing the possibility of future problems".

In behavioral analysis, social skill is a name given to learned behaviors that, when presented in a context, increases the probability to a positive social interaction. The term social skilled here qualifies the individual interaction behaviors. Based on a behavioral analysis, it is not correct to consider an individual social ability or inability as an explicative variable of easy or difficult social interaction. To say that someone has difficulty interacting because that person is socially skilled is a tautological explanation as many others warned by behavioral analysis. Social skill can be understood as a behavior that, like any other, has a role in its context, being functional or maintained by the environmental consequences (environment meaning social and interpersonal contexts). Behaviors will be classified as skilled or not skilled depending on the context.

Caballo (2003) describes the operational analysis of the term social skill. He says that it consists on being capable of initiating and maintaining a conversation; public speaking; express love, care and preferences; defend the own rights; ask for favors; turn requests down; congratulate and be congratulated; express opinions even in disagreements; express and justify when harmed, tired, unpleased; apologize or admit lack of knowledge; ask for change in others behavior and receiving criticism.

According to Del Prette and Del Prette (2001) socially skilled behavior is described as following: a) communication social skills (ask and answer questions; reward and complement; ask and give feedback in social interaction; initiate, maintain and finish conversation; duration, latency and adequate regulation of speech); b) civility social skills (to say please; thanks; self presentation; to say hello; to say goodbye); c) assertiveness and coping social skills (to show opinions, agree, disagree; to make, accept and decline requests; to apologize and admit failure; to establish a affection/sexual relationship; interact with 
Environmental influence on the development of social skills in children

authorities; to deal with critics); d) empathic social skills (paraphrase, reflect feelings and express support); e) work social skills (to lead groups, speak in public; to solve problems, to make decisions and deal with conflicts; educational social skills); and f) social skills of positive feelings expression (to make friends; express solidarity and cultivate love).

The operational analysis of social skills as a group of specific behaviors shows us some of the social skills that are valorized on the occident. It is important to remember that if the development of such skills begins in childhood, the individual's chances to have an adjusted behavior in its social-cultural environment as an adult enhances.

\section{SOME RANGES OF CHILDREN SOCIALLY SKILLED BEHAVIOR}

Among the response component of the largest behavioral range of social skills, some necessary behaviors needed to achieve an adequate social development in childhood have been selected for analysis. Those described as socially skilled are countless, learned on different stages of the child's development, and under different contingencies. Table 1 presents some of those behaviors, based on Silva, Del Prette and Oishi (2003), Lemos and Menezes (2002) and Del Prette and Del Prette (2001). This paper does not aim to describe "closed" categories of social skills as does the structural framework. Some ranges of functional behaviors, described and considered socially skilled in Brazilian culture, will be presented. As learned behavior, a social skills repertoire can be developed in childhood if the educator knows what behaviors must be thought.

Behavior listed on Table 1, when appropriately presented by the child, help its social development as they allow positive interaction with peers and adults.

Some self-control behaviors (to wait, to think before acting; to do something unpleasant) contribute in acquiring new behaviors, as to follow rules, to finish tasks, to do group assignments, and others. Those skills are essential to peer's interaction and must be used when in the school context. To develop self-control is an important aspect on preventing delinquent and anti-social behavior (Reid, Patterson \& Snyder, 2002).

The so called civility social skills, according to Del Prette and Del Prette (2001), refer to many social rules known in Brazilian culture as "good manners" or "politeness". Those who do not follow those rules can be marginalized, depending on their social group.

As the child develops, developing abilities such as saying please or apologizing, helps them in learning: a) to discriminate that others have the same rights and needs, and to 
properly ask for something, and b) that each group member must repair a mistake that, in some way, harmed the other. By apologizing the child also learns to be responsible for its acts, good or bad. The consequences given by social context to those socially skilled as the attendance to a polite request or the reestablishment of a significant social contact after an apology, contribute to reinforce and maintain those behaviors.

Behavior ranges defined by cooperation, social availability, assertiveness and empathic social skills are important to children in preschooler and scholar ages, when peer interaction enhances. Children presenting those abilities are more likely to be accepted by peers. Once accepted, they are more likely to feel part of the group and to develop better self-esteem and self-image. In addition, having those skills makes them to be welcomed to participate in peer activities, and enhance their chances to interact and to develop new behaviors.

Academic social skills help children in the learning process, seeming to make it easier. According to some studies, there is evidence that link social competence with academic accomplishment. Though not yet proven to be by chance, Lemos and Meneses (2002) show that children with learning difficulties, when compared to children with normal academic accomplishments, have different social competencies. They are not as well accepted or more rejected by peers, they show deficit in many positive social behaviors, and show higher levels of negative social behavior.

Thus, it can be said that creating conditions that favor the development of children's behaviors (shown on Table 1), seems important to prevent behavioral problems. When the environment does not present such conditions, the child can learn other concurrent behaviors that, on the contrary, make it more difficult establish positive social interaction. 


\begin{tabular}{|c|c|c|}
\hline $\begin{array}{l}\text { RANGES OF } \\
\text { CHILD } \\
\text { BEHAVIOR }\end{array}$ & DEFINITION & EXAMPLES \\
\hline $\begin{array}{c}\text { Self-control } \\
\text { behavior }\end{array}$ & $\begin{array}{l}\text { "Self-control refers to the emission of } \\
\text { (...) a controller response, [that] affects } \\
\text { variables in a way that modifies the } \\
\text { probabilities of other, the controlled one. } \\
\text { Often the individual comes to control } \\
\text { part of it's behavior when a response has } \\
\text { consequences that leads to conflicts - } \\
\text { when leads to as much positive as } \\
\text { negative reinforcement" (Skinner, } \\
\text { 1953/1998, p. 252-253). }\end{array}$ & $\begin{array}{l}\text { Preschool age: } \\
\text { Can wait; respects limits; tolerates } \\
\text { frustration; does what doesn't like or } \\
\text { doesn't want when necessary. } \\
\text { School age: } \\
\text { Thinks before talking and acting, controls } \\
\text { humor before teasing or pressure; controls } \\
\text { the expression of negative and positive } \\
\text { feelings before colleagues and adults; } \\
\text { accepts critics. }\end{array}$ \\
\hline $\begin{array}{l}\text { Assertive } \\
\text { behaviors }\end{array}$ & $\begin{array}{l}\text { "Behavior that makes it possible to act } \\
\text { despite the own interests, to express } \\
\text { without excessive anxiety, to express true } \\
\text { feelings without embarrassment or to } \\
\text { exercise rights considering others" } \\
\text { (Alberti \& Emmons, 1978, p.18). }\end{array}$ & $\begin{array}{l}\text { Preschool age: } \\
\text { To express desires and preferences; to } \\
\text { express affection and feelings of } \\
\text { displeasure, to make friends; initiate } \\
\text { conversation; to play together; } \\
\text { lead/propose games; complain of a } \\
\text { colleague to the teacher; to say no; to tell } \\
\text { the truth after doing something wrong; to } \\
\text { express positive feelings. } \\
\text { School age } \\
\text { To criticize; question rules politely; to } \\
\text { discriminate the right moment to express } \\
\text { opinions; to value itself; express } \\
\text { displeasure politely; to Express rights and } \\
\text { needs; to Express opinions; to end } \\
\text { conversations; to ignore/not response to } \\
\text { teasing to accept with humor mocking } \\
\text { from friends; to respond assertively to } \\
\text { name calling or unfair critics; ask a } \\
\text { colleague to stop bothering; convince a } \\
\text { colleague to do something; to negotiate } \\
\text { and win disputes. }\end{array}$ \\
\hline $\begin{array}{c}\text { Civility } \\
\text { behaviors }\end{array}$ & $\begin{array}{l}\text { These behaviors "refer to patronized } \\
\text { achievements, in transactions between } \\
\text { people in the regular and ceremonial } \\
\text { contexts. When put together with } \\
\text { communication skills, they express } \\
\text { courtesy" (Del Prette \& Del Prette, } \\
\text { 2001, p. 72). }\end{array}$ & $\begin{array}{l}\text { Preschool age } \\
\text { To say please and ask for excuse; to thank } \\
\text { (for example, to thank colleagues for } \\
\text { favors they did and for complements); to } \\
\text { say goodbye; to apologize after doing } \\
\text { something wrong. } \\
\text { School age } \\
\text { To introduce itself, to greet others. }\end{array}$ \\
\hline $\begin{array}{c}\text { Cooperation } \\
\text { and social } \\
\text { availability } \\
\text { behaviors }\end{array}$ & $\begin{array}{l}\text { These behaviors refer to the individual's } \\
\text { skill to expose itself in a social situation } \\
\text { to act in its own interest and identify the } \\
\text { other's needs and offer help, doing a } \\
\text { joint task or helping the other to do it. }\end{array}$ & $\begin{array}{l}\text { Preschool and school ages } \\
\text { To follow rules, to make and attend } \\
\text { requests; to ask and to answer questions; } \\
\text { seek for parents attention to offer help; to } \\
\text { pay attention to what's being said (to } \\
\text { listen). }\end{array}$ \\
\hline
\end{tabular}




\begin{tabular}{|c|l|l|}
\hline $\begin{array}{c}\text { Empathic } \\
\text { behaviors }\end{array}$ & $\begin{array}{l}\text { "Empathic behavior includes: a) a } \\
\text { cognitive component, characterized by a } \\
\text { capacity to understand accurately the } \\
\text { others perspectives and feelings; b) a } \\
\text { affective component, characterized by } \\
\text { feelings of compassion/care towards } \\
\text { others. c) a behavioral component, } \\
\text { meaning both verbal and non-verbal } \\
\text { manifestations of understanding the } \\
\text { other's internal state." (Falcone, 2000, } \\
\text { p.51). }\end{array}$ & $\begin{array}{l}\text { School age } \\
\text { To complement colleagues; to give consol } \\
\text { to a sad colleague; to express support, to } \\
\text { show the willing to share difficulties or joys } \\
\text { with colleagues. }\end{array}$ \\
\hline $\begin{array}{c}\text { Academic } \\
\text { skilled } \\
\text { behaviors }\end{array}$ & $\begin{array}{l}\text { To give responses that helps the } \\
\text { interaction with the teacher and with } \\
\text { colleagues favoring the teaching-learning } \\
\text { process. }\end{array}$ & $\begin{array}{l}\text { Preschool age } \\
\text { To ask questions to the teacher in class, to } \\
\text { ask for the teachers and the colleagues help } \\
\text { when doing exercises, to pay attention in } \\
\text { class. } \\
\text { School age }\end{array}$ \\
& $\begin{array}{l}\text { To do the homework; to be responsable } \\
\text { for the presentation and content of } \\
\text { assignments; to finish tasks on time; to } \\
\text { organize the own school material; to study; } \\
\text { to discuss subjects in class; to work in } \\
\text { groups. }\end{array}$ \\
\hline
\end{tabular}

Table 1: Some ranges of child behaviors classified as socially skilled in Brazilian culture.

\section{ABOUT TEACHING SOCIAL SKILLS DURING CHILDHOOD}

The family, considered important to the development of the child's social skills, has a unique role towards their development. A child is not born having a latent system of values and rules ready to be developed, but instead, an amazing ability to learn. Many of the parent's behaviors, words and gestures are being observed and learned, and they become part of this environment. At the same time, the environment changes the child's behavior, the child changes the environment. Knowing that, parents must dominate the appropriate strategies to educate their children.

When raising children, it is very important for parents to try giving their children an appropriate education. In addition, parents must learn to see their children's needs in order to attend them in a loving and understanding way. They must add empathy - to put yourself in their place - to firmness when dealing with their children. It's necessary to understand the child's feelings and make it clear that they are understood. So the parents task is not just to raise "polite" children, but children who feel loved, who are good citizens, who are capable of expressing their rights and capable of respecting others. This means, to raise socially skilled children that can be loved and understood. 
Environmental influence on the development of social skills in children

So it can be said that the family environment can promote socially skilled behaviors in children, and avoid inappropriate behaviors. When parents are a model of adequate behavior, when they have positive and consistent educational actions and value their children's adequate behaviors, they are contributing to the development of socially skilled behaviors. On the other hand, when parents use punishments rather than reinforcing methods to pressure the child to behave as they would like, the results are behavioral problems and social skill deficits, and the child may become socially incompetent in addition to many difficulties regarding family interaction.

\section{CONCLUSION}

This paper is destined for professionals working with families, directly with the child or guiding parents, providing a material to clarify issues about some socially skilled behaviors that are important and rewarded in Brazilian culture to achieve an appropriate peer interaction.

Behaviors here presented as socially skilled do not include all necessary behaviors to an appropriate socialization, because, depending on the context, the individual may present one or another behavior. There are behaviors not listed on this paper that are equally important. The professional must analyze the contingencies with parents or teachers and define which behavior will be more adequate in each context, and plan conditions for the child's learning.

When working in the area of prevention with children, whose capacity of learning is very high, a large step is taken towards a larger control and prediction of human behavior. To predict and to control its own behavior, gives us the possibility to have a conscientious and adequate interaction with the environment and to attend the numerous demands of the various contexts around us.

\section{REFERENCES}

ALBERTI R. E., \& EMMONS, M. L. (1978). Comportamento Assertivo: Um guia de autoexpressão. Belo Horizonte: Interlivros.

CABALLO, V. E. (2003). Manual de Avaliação e Treinamento das Habilidades Sociais. São Paulo: Santos. (Original work published in 1986). 
Environmental influence on the development of social skills in children

DEL PRETTE, A., \& DEL PRETTE, Z. A. P. (1999). Psicologia das Habilidades Sociais: Terapia e Educação. Petropólis: Vozes.

DEL PRETTE, A., \& DEL PRETTE, Z. A. P. (2001). Psicologia das Relações Interpessoais: Vivencias para o Trabalho em Grupo. Petropólis: Vozes.

FALCONE, E. (2000). A evolução das habilidades sociais e o comportamento empático. In E. F. M. Silvares (Ed.), Estudos de caso em psicologia comportamental (pp. 49-77). Campinas: Papirus.

GOMIDE, P. I. C. (2001). Efeitos das práticas educativas no desenvolvimento do comportamento anti-social. In M. L. Marinho, \& V. E. Caballo (Eds.), Psicologia Clínica e da Saúde (pp. 33-53). Londrina/Granada: UEL/APICSA.

LEINER, M. (2010). Niñez en riesgo: El impacto de la violencia en Ciudad Juárez. Ciudad Juarez: El Colegio de Chihuahua.

LEINER, M., \& MARINHO-CASANOVA, M. L. (2011). Formação em Ação social 1: Treinamento para resolver problemas sociais em crianças pequenas. Londrina: Idealiza.

LEINER, M., \& MARINHO-CASANOVA, M. L. (2014). Formação em Ação social 2: Treinamento para resolver problemas sociais em crianças pequenas. Londrina: Midiograf.

LEMOS, M. S., \& MENESES, H. I. (2002). A avaliação da competência social: versão portuguesa da forma para professores do SSRS. Psicologia: Teoria e Pesquisa, 18, 267-274.

MARINHO, M. L. (2003). Comportamento anti-social infantil: Questões teóricas e de pesquisa. In A. Del Prette, \& Z. A. P. Del Prette (Eds.), Habilidades Sociais, Desenvolvimento e Aprendizagem (pp. 61-81). Campinas: Alínea.

MARINHO, M. L., \& Caballo, V. E. (2001). Da desobediência infantil a personalidade anti-social em adultos. Pediatria Moderna, 37, 94-99

MARINHO-CASANOVA, M. L. (2015). Escola de Valores: experiências de um projeto na comunidade para prevenção da violência e do uso de drogas com crianças. In S. G. Murta,

C. LEANDRO-FRANÇA, K. B. SANTOS, \& L. POLEJACK (Eds), Prevenção e promoção em saúde mental: Fundamentos, planejamento e estratégias de intervenção (pp.654-676). Novo Hamburgo: Sinopsys.

REID, G. R., PATTERSON e SNYDER, J. (2002). Antisocial behavior in children and adolescents. A developmental analysis and model for intervention. Washington: American Psychological Association.

RODRIGUES, P. M. B., \& MARINHO M. L. (2007). Orientação para pais para prevenir problemas de comportamento em crianças. In R. R. Starling (Ed.), Sobre Comportamento e Cognição (pp.88-103). Santo André: ESETEC.

ROTHER, E. T. (2007). Revisão sistemática X revisão narrativa. Acta Paulista de Enfermagem, 20, v-vi.

SILVA, A. T. B., DEL PRETTE, A. e OISHI. (2003). Habilidades sociais de pais e problemas de comportamento de filhos. Argumento, 9, 11-29. 
Environmental influence on the development of social skills in children

SKINNER, B. F. (1998). Ciência e comportamento bumano. 10ª ed. São Paulo: Martins Fontes. (Original work published in 1953).

ULLMAN, L. P., \& KRASNER, L. A. (1975). A psychological approach to abnormal behavior. New Jersey: Prentice-Hall. 